Article

\title{
Levers of Control for Supply Chain Sustainability: Control and Governance Mechanisms in a Cross-Boundary Setting
}

\author{
Joost de Haan-Hoek, Wim Lambrechts *(D), Janjaap Semeijn and Marjolein C. J. Caniëls \\ Faculty of Management Sciences, Open University of the Netherlands, PB 2960 Heerlen, The Netherlands; \\ joost.de.haan@gmail.com (J.d.H.-H.); janjaap.semeijn@ou.nl (J.S.); marjolein.caniels@ou.nl (M.C.J.C.) \\ * Correspondence: wim.lambrechts@ou.nl
}

Received: 11 February 2020; Accepted: 11 April 2020; Published: 15 April 2020

check for updates

\begin{abstract}
The rise of global supply chains as well as attention to the Triple Bottom Line provides organizations with new conditions and strategy paradoxes to be dealt with when it comes to sustainability in supply chain management. This study of a large multinational organization with a strong Triple Bottom Line focus provides a comprehensive analysis of the use of control and governance mechanisms in supply chain context. Through the Levers of Control framework, the application of these mechanisms both internally and across organizational boundaries is shown. The interplay between levers helps in dealing with the in itself paradoxical nature of Triple Bottom Line goalsetting. The results show that the "softer" elements of the Triple Bottom Line, i.e., People and Planet, are approached with the lever associated with the beliefs system, which in turn enforces the boundary and interactive control systems. Ultimately, applying the Levers of Control in supply chain context might contribute to pursuing a holistic approach of sustainable supply chain management.
\end{abstract}

Keywords: levers of control; triple bottom line; sustainable supply chain management; control; governance

\section{Introduction}

Supply chains have expanded all around the globe, and while this globalized context brings many opportunities for multinational corporations (MNCs), it also brings challenges related to environmental pressure and risks of social misconduct [1]. With the philosophies of "no organization is an island" and "cooperation to achieve profit", one could argue that the same applies for pursuing sustainability. While profitability lends itself to be measured relatively easily in money, sustainability provides goals that are vaguer and may involve increased costs. The topic brings new strategy paradoxes to the table [2] and shows a refinement of the conditions with which a contemporary organization must deal [3], as well as new challenges for management when it comes to the question of how to achieve these goals within this greater context of the supply chain.

Globalization has led to increased complexity and uncertainty of production processes and supply chains. When it comes to ethical and sustainable sourcing, a MNC might have control over its first tier suppliers, but what happens further upstream in the supply chain is not always clear and visible. The notion of Sustainable Supply Chain Management (SSCM, also referred to as Green Supply Chain Management-GSCM; see [1] for an overview of synonyms and descriptions) has been defined and described in a variety of ways [1]. Giminez and Sierra [4] discussed several governance mechanisms for greening suppliers, while Giminez and Tachizawa [5] provided leads for methods of supplier assessment, as well as arguments for a collaborative approach. Schmidt, Foerstl, and Schaltenbrand [6] used an integrated threefold approach to green the supply chain, taking into account green supply chain management practices, the supply chain position, as well as the bottom line of economic performance. 
The existing research often follows a familiar duality in organizational issues, for example cost/benefit, time/quality or risk/incentives, whilst actually a multitude of factors is involved. In addition to classical trade-offs, a Triple Bottom Line (TBL) stemming from the principles of corporate social responsibility (CSR) [7], now requires attention: social and environmental performance must be considered in addition to economic gains. In a study on the implementation of CSR, Bhardwaj [8] suggests further research to expand the understanding of this relationship by combining it with other points of view and showing implications for managers that can be discussed in comparison with other control and governance literature. The TBL poses new challenges, not only for executing departments such as purchasing but also for management when it comes to subjects such as goalsetting, control and governance.

Management literature offers a multitude of control and governance mechanisms that can be used by managers for performance measurement. The levers of control (LOC) framework by Simons [9] allows for a comprehensive classification, yet in practice, not all levers are taken into account or a narrow interpretation is used, "In previous research, the role of PMS [performance management systems] has been mostly a diagnostic one with emphasis on monitoring performance. Research looking at other aspects of Simons' MCS [management control system] uses (interactive, beliefs and boundary) is limited" [10] (p. 128). Furthermore, these mechanisms are often applied within one single organization, but the question is whether the same tools and tactics could be applied across organizational boundaries. When it comes to supply chain management, scholars have suggested a holistic approach in management, as if it were a single entity [11], to ensure efficiency and optimization of value. It seems logical to apply a comparably holistic approach towards social, environmental and economic performance, along the lines of the concept of Supply Chain Responsibility (SCR) [12].

The question remains which company will take the leading role in the supply chain, i.e., as supply chain director when it comes to these initiatives. Achieving TBL goals is often at odds with striving for short-term profits. The lesser known and less powerful suppliers may be less inclined to pursue all three bottom lines, while large MNCs are increasingly being viewed as having a certain responsibility towards people and planet. Hence, large MNCs, in their role as supply chain director, should convey the full TBL across their organizational boundaries using internal control and governance practices that cover all these three elements. New insights are needed about what MNCs do to achieve TBL goals within their supply chain. This study will focus on how the use of control and governance practices in the context of SSCM influences the TBL performance of a multinational organization.

\section{Theoretical Background}

\subsection{Triple Bottom Line}

The concept of TBL, also referred to as Triple-P, or People, Planet and Profit/Prosperity, was originally introduced by Elkington [13], aiming to incorporate both an organization's environmental and social impact, in addition to the economic bottom line for viewing organizational performance. These driving forces echo to a certain extent the "new conditions" of the second half of the 20th century that have been pointed out by Child [3]: "Globalization, new technologies, the knowledge-based society, hypercompetition, and the social expectations placed on business are each creating new demands upon organization" [3] (p. 56). These and other factors shape the competitive landscape as they require organizations to make strategic choices and adapt to this new situation. The TBL thereby enhances understanding of sustainability by adding information regarding an organization's social, human and environmental capital to the economic and shareholder values [14]. TBL became a popular management concept in organizations; however, the lack of a holistic and systematic approach is criticized by its founder Elkington [15].

The TBL framework provides organizations with the possibility to more adequately measure organizational performance [16]. An often heard criticism of the TBL theory is that the profit bottom line is measurable, but one should be critical and look deeper into the measurement of performance 
of the people and planet bottom lines as they are less easily defined and quantified in an objective manner [8]. This shows a need for other management control and governance practices of a less mechanical nature to be applied in order to pursue all bottom lines simultaneously. Sridhar and Jones [17] point out the fallacy in the theory that the TBL approach would be an integrated system, yet they see in practice that the bottom lines are parallel to each other: "In practice, the TBL focuses on the co-existence of the three bottom lines but doesn't show their interdependence. The consequences include a tendency to ignore the profound interdependence of these factors, and to see them as likely to be conflicting rather than potentially complementary" [17] (p. 98). So the true value of TBL would not simply lie in the addition of two dimensions (people and planet), but in the integrated combination of the three and their interaction that influences an organization's performance.

Another criticism by Sridhar and Jones [17] concerns "the desire to be compliant and whether TBL, as an institutionalized norm, pushes corporations to be compliant or go beyond compliance" [17] (p. 98). Their sentiment seems to be that the use of the TBL concept stems from compliance rather than commitment, comparable to the question that can be asked regarding the sincerity, or that having the interest in all three dimensions actually still is in service of one of them: the P of profit. This is also part of the criticism of TBL founding father Elkington [15] who had hoped the theory would lead to organizational change rather than simply a performance accounting tool.

\subsection{Sustainable Supply Chain Management}

According to Carter and Rogers [18], sustainability exists at the intersection of the three bottom lines and, accordingly, SSCM therefore involves "systemic coordination of key interorganizational business processes for improving the long-term economic performance of the individual company and its supply chains" [18] (p. 368), pointing out the need for coordination to achieve said sustainability in the light of economic performance. In addition, they also state that "we are not suggesting that organizations blithely undertake social and environmental goals relating to the supply chain", thereby referring to the extra costs that these people and planet goals would bring to an organization [18] (p. 369).

Such interpretations, in which SSCM is reduced to the supremacy of financial and economic dimensions over environmental and social dimensions, are criticized by Pagell and Shevchenko [19], who state that "the question of how to create truly sustainable supply chains remains unanswered" [19] (p. 44). "True SSCM" in their eyes might then be defined as follows: "To be truly sustainable a supply chain would at worst do no net harm to natural or social systems while still producing a profit over an extended period of time; a truly sustainable supply chain could, customers willing, continue to do business forever" [20] (p. 38). While the profit bottom line is still vital, the people and planet bottom lines also have a bare minimum in this definition.

It is clear that different definitions and interpretations are available for SSCM, ranging from a narrow focus towards environmental issues (also referred to as Green Supply Chain Management, GSCM), to a holistic interpretation of economic, environmental, social and ethical aspects in the supply chain [21,22]. As a result of a systematic literature review, Seuring and Müller [23] present a conceptual framework for SSCM, consisting of three elements: (1) triggers for SSCM; (2) supplier management for risks and performance; and (3) SCM for sustainable products. They also point towards the finding that sustainable development is often reduced to environmental issues, and that a theoretical background is often missing for SSCM [23]. Other conceptualizations emerged as well, such as Closed Loop Supply Chains, related to circular economy, and focusing on return processes and value capture related to this [24-26]; and Low Carbon Supply Chain (LCSC) management, focusing on lowering carbon footprints related to supply chain activities and production processes [27]. Seuring and Gold state that "Effectively integrating sustainability into firms requires action that exceeds organizational boundaries" [28] (p. 1), and Cruz calls for a holistic approach of SSCM: "Each stage in the supply chain gives rise to its own effects, impact, and opportunities for improvement, but effective CSR strategies require an analysis that encompasses the entire supply chain" [29] (p. 234), where CSR strategies could 
also be read as strategies fitting the people and planet dimensions. This holistic approach is suggested to be developed in a network approach. Once again, the boundaries of a single organization are crossed in this advice; but also the arguments in favor of pursuing the people and planet dimensions involve the profit dimension. Putting effort into CSR (or people and planet) is described by Cruz [29] as a long term (financial) investment that should be treated as such.

The TBL approach and other CSR approaches have contributed to developing a business case logic to integrate sustainability and foster sustainable supply chains [30,31]. The TBL concept can be viewed as a part of SSCM, and control and governance mechanisms are needed to facilitate this connection and collaboration on the different dimensions. The broad and inclusive definition of SSCM formulated by Ahi and Searcy [21] includes all relevant factors: "The creation of coordinated supply chains through the voluntary integration of economic, environmental, and social considerations with key inter-organizational business systems designed to efficiently and effectively manage the material, information, and capital flows associated with the procurement, production, and distribution of products or services in order to meet stakeholder requirements and improve the profitability, competitiveness, and resilience of the organization over the short and long-term" [21] (p. 339). This definition acknowledges the TBL and the need for their integration, as well as the importance of the financial element for continuation of the organization.

Yet with the recent critique on how the TBL has been interpreted during the past 25 years, the call for a holistic approach in SSCM and the alignment of SSCM and TBL approaches need to be revisited. This is reflected in the following definition of SSCM, provided by Lambrechts [1]: "Sustainable Supply Chain Management (SSCM) is the integration of environmental and social impact along the procurement and production processes of a focal company and its suppliers, as well as the distribution of its products and services towards customers. SSCM thereby can focus on making existing supply chains sustainable, as well as making products and services themselves sustainable. Ultimately, SSCM contributes to a holistic and long-term strategic perspective of a company and its supply chain, thereby going beyond formal accountability, environmental and social regulations as imposed by governments, and goes beyond perspectives regarding the Triple Bottom Line as a balancing act" [1] (p. 2). This definition both mentions the aspect of going beyond accountability, as well as adopting a holistic and systemic notion that is critical towards what could be called "traditional" or "trade-off" TBL approaches $[1,15]$.

\subsection{Supply Chain Director}

A supply chain is often shaped and pushed in certain directions as a consequence of the actions of the biggest/strongest organization in the chain, a position that can be referred to as the supply chain director [32]. Spence and Bourlakis [12] advocate the importance of long term commitment and partnership chain-wide in regards to the social responsibility in the supply chain, rather than one where the biggest/most dominant player in the chain (the 'watchdog') determines the others' activities in an effort for risk management. Spence and Bourlakis [12] do not deny that there are dominant players, but they imagine different methods for that role. A supply chain director thus needs a multifaceted control and governance approach, so that it is not just a top down method of steering the supply chain.

Bridging the gap between buyer and supplier towards a combined effort (or partnership) should help with the sincerity of effort and commitment that is put into sustainability practices, which would in theory lead to improved effectiveness. According to Foerstl et al. [33], suppliers must understand the sustainability priorities of customers and stakeholders for effective focus and depth upstream. Customers increasingly hold the focal company responsible for what happens upstream in their supply chain. Social misconduct or unethical behavior happening at the premises of first, second or third tier suppliers, negatively influences consumer perception about the brand owner. This mechanism is called "guilt by association" and has been documented in extended supply chain context as well [34]. Therefore, the integration of marketing and procurement is essential to encourage first-tier suppliers to actual commitment rather than compliance. External pressures from stakeholders are ever present 
and influential on strategic choices and yet on their own not pressing enough for organizations further upstream in supply chains to fully commit to sustainable practices [33]. Once again, the economic dimension proves to be a driving force behind adherence to the complete triple bottom line as the willingness to do so increases with the opportunities for a supplier to leverage its efforts for sustainability into a competitive advantage.

Within the context of MNCs, the corporate purchasing function demonstrably facilitates the adoption of CSR practices and initiatives upstream [35,36]. Depending on the type of buyer-supplier relations, these upstream activities in light of sustainable and ethical sourcing, can be oriented towards different approaches of supplier assessment, development, collaboration [1]. Following a high buyer demand of CSR initiatives in supply chain context [37], a variety of management systems and monitoring approaches has been developed, yet there effectiveness with regard to delivering adequate CSR results is still contested [38,39]. A recent study by Bartczek [40] however shows that Socially Responsible Purchasing (SRP) is a driving force of CSR behavioral alignment among the single actors of a (textile) supply chain. It was empirically observed that buyer SRP has a considerable effect on supplier SRP performance, i.e., with effects beyond the first-tier suppliers.

\subsection{Control and Governance}

Governance approaches for inter-organizational relations can be classified in a number of ways, one of which is the division into contractual and relational governance. The first is a rule-oriented and formal approach, with precisely defined expectations for output, processes, rights, etcetera. The second is based on trust between the organizations. Cao and Lumineau [41] found that these two types of governance are complementary and work best when there is an interplay between them, with the approaches improving each other's effectiveness as a result. Being aware of the interplay between different governance mechanisms is specifically important within the context of complex buyer-supplier relationships [42].

When a buyer can trust that a supplier is on the same wavelength when it comes to TBL goals, relational governance is more at play. The complexity and uncertainty of sustainability makes it difficult to set stable performance specifications, hence relying on contractual governance alone is insufficient. Instead, balancing contractual and relational governance mechanisms is necessary for successful sustainability integration, echoing the value of interplay between the types of governance [43]. Furthermore, supply chain relations influence this process, especially when it comes to complex topics like sustainability and information asymmetry [44].

The methods of management control discussed earlier are part of the more technical cybernetic approach of control (more similar to the contractual approach of governance), but the scholars in the more behavioral oriented approach have their doubts about how malleable reality is: "The primary function of management control is to influence behaviors in desirable ways. The benefit of management control is the increased probability that the organization's objectives will be achieved" [45] (p. 43). A distinction made by Merchant and van der Stede [45] is between three objectives of control: (1) action controls, (2) result controls, and (3) personnel and cultural controls. The first two are closer to the technical approach discussed earlier, but the third, for example, also involves unwritten and informal rules for behavior. The latter might be a better approach to managing (internal) commitment to pursue people and planet, as the less exact nature of both those bottom lines seems a better fit with such personnel and cultural controls.

Simons [9] provides managers with four "levers of control" (LOC), with which they can influence their employees. The LOC are: (1) diagnostic control systems; (2) beliefs systems; (3) boundary systems; and (4) interactive control systems. The first type is more technical in nature and oriented towards performance measurement. The second interlinks with sincerity and commitment, as it has the goal of having the employees to fully embrace the core values of the company. The third lever entails the setting of boundaries of what is (un)acceptable behavior. Within these boundaries anything is allowed, but because of the clear limits, it is all risk free. The fourth lever, interactive control systems, 
involves a rich exchange of information, providing the opportunity for organizational learning and possibly discovering both potential risks and opportunities. Together the LOC form a framework for control and governance mechanisms that can be used in different ways. Hoque and Chia [10] describe the effects of the application of the LOC specifically in a multinational just after a merger and the positive effects the cultural change had on the adaption of the business strategy and performance. They argue that the power of the four levers lies in how they work together and complement each other $[9,46]$. Gond et al. [47] juxtapose diagnostic control systems and interactive control systems as competing systems in their analysis of sustainability control systems. Others, like Tessier and Otley [48] further interpret the framework along the lines of Simons' division of the four levers into two categories, positive (beliefs and interactive control systems) and negative (diagnostic control and boundary systems). This shows the versatility and broad usability of the LOC framework.

If Simons' concept of LOC is altered slightly, changing the "employees" as the ones influenced by the different control systems in the concept into "suppliers", then the LOC provide a control system that would fit within the bigger picture of supply chain management, where the chain is seen and managed as a single entity.

\section{Materials and Methods}

\subsection{Research Design}

This study adopts a case study design, which is, according to Yin [49], the preferred method for "examining contemporary events, but when the relevant behaviors cannot be manipulated" [49] (p. 11). A case study design also enables to replicate the research in similar situations with different case organizations.

Our study presents an embedded single case research, as it concerns specific units of analysis of the TBL, governance and control, within relevant parts of the organization. It is a typical case [49] (p. 48), with a specific focus for sustainability oriented international organizations, aiming to fill a gap in research on the use of different control and governance practices (using the full LOC framework) and their use in the context of SSCM. The lessons learned from this case can be assumed to be representative for other multinational organizations of comparable size, who experience similar pressures and expectations. It is a qualitative research with a descripto-explanatory nature, and as the boundaries between phenomenon and context are somewhat fluid with case studies like this one according to Yin [49] (p. 18), it allows some room for a line of reasoning from exploration. The research design allows for an in-depth analysis of the topic within a real-life context.

The case in this study is a US multinational: a global medical technology company with around 50,000 employees across 50 countries. It has prominent policies and strategies on sustainability and this has led to a high position in the Dow Jones Sustainability Indices (DJSI), and a spot in the top 100 Best Corporate Citizens list 2017 of the Corporate Responsibility Magazine. As a sizeable multinational organization, it has an important role in its supply chain, similar to the supply chain director conceptualization as described in the literature review. It sources from all around the globe, whilst challenging itself to do so in a sustainable manner. This makes it a relevant case for this research.

\subsection{Data Collection}

For the collection of data, a triangulation of methods was used: Analysis of policy documents, analysis of (internal and external) organizational performance reports (Table 1), and ten semi-structured interviews with key informants (Table 2). A number of interviews were done on location at the case organization, which made a number of observations possible as well. 
Table 1. Internal and external organizational performance reports used in the analysis.

\begin{tabular}{ccc}
\hline Source & Focus & Type of Report \\
\hline 1. [Organization]'s Expectations for suppliers & Internal & Policy \\
2. [Organization]'s Environment, Health and Safety policy & Internal & Compliance \\
3. Sustainability Report 2016 (GRI-G4) & External & Communication \\
4. Sustainability Report 2014 (GRI-G4) & External & Communication \\
5. Sustainability Performance Update 2015 & Internal & Policy \\
6. Annual Report 2015 & External & Communication \\
7. California transparency in supply chains act disclosure & External & Compliance \\
8. [Organization]'s Company Showcase stories & External & Communication \\
9. Internal guidelines and documents & Internal & Policy \\
10. Internal company presentation & Internal & Communication \\
\hline
\end{tabular}

Table 2. Interviewees.

\begin{tabular}{ccc}
\hline Position & $\begin{array}{c}\text { Years of } \\
\text { Experience }\end{array}$ & Location \\
\hline $\begin{array}{c}\text { Senior Director Supply Chain Operations EMEA } \\
\text { World Wide Project and Sustainability Coordinator }\end{array}$ & $30+$ & Belgium \\
Director, Sterilization and Utilities Global Operational & $20-30$ & France \\
Excellence COE & $10-20$ & USA \\
Global product manager lab automation Marketing & $1-5$ & The Netherlands \\
department Life Sciences & $1-5$ & The Netherlands \\
Core Team Leader Life Sciences & $1-5$ & The Netherlands \\
The Netherlands \\
Probal demand and supply planner Global Procurement & $1-5$ & The Netherlands \\
Facility manager & $1-5$ & Belgium \\
Director Global Product Stewardship & $10-20$ & Belgium \\
REACH Program Support Analyst & $1-5$ & \\
\hline
\end{tabular}

\subsection{Operationalization}

In order to effectively develop interview guidelines, the constructs that are central in this research are defined and operationalized. Table 3 presents the operationalization of the key constructs.

Table 3. Operationalization of constructs.

\begin{tabular}{ll}
\hline Control & $\begin{array}{l}\text { A generalized term for the process of management control, "the process by which } \\
\text { managers at all levels ensure that the people they supervise implement their } \\
\text { intended strategies" [50] (p. 11). This covers performance measurement as well as } \\
\text { performance management. }\end{array}$ \\
\hline $\begin{array}{l}\text { Performance } \\
\text { measurement }\end{array}$ & $\begin{array}{l}\text { Performance measurement is about 'seeing' how an organization is doing, in } \\
\text { comparison to its aims and objectives. It is a way of gauging how well (or not) an } \\
\text { organization is doing against its short and long-term goals and targets" [51] } \\
\text { (p. 123). Related term: assessment. }\end{array}$ \\
\hline $\begin{array}{l}\text { Performance } \\
\text { management }\end{array}$ & $\begin{array}{l}\text { An extension from performance measurement, as it is "continually (re)designing, } \\
\text { monitoring and acting upon such measures" [51] (p. 123). }\end{array}$ \\
\hline Objectives of control & $\begin{array}{l}\text { (1) Action controls, (2) result controls and (3) personnel and cultural controls. The } \\
\text { first two are closer to the technical approach of control; the third for example also } \\
\text { involves unwritten and informal rules for behavior [45]. }\end{array}$ \\
\hline $\begin{array}{l}\text { Management control } \\
\text { problems }\end{array}$ & \begin{tabular}{l} 
(1) Lack of direction, (2) motivational problems, (3) personal limitations [45]. \\
\hline
\end{tabular}
\end{tabular}


Table 3. Cont.

\begin{tabular}{ll}
\hline Levers of control (LOC) & (1) Diagnostic control systems; in line with performance measurement. \\
& (2) Beliefs systems; having the employees to fully embrace the core values of the \\
& company. \\
& (3) Boundary systems; the setting of boundaries of what is unacceptable behavior, \\
often formalized in "standards of ethical behavior and codes of conduct". & (4) Interactive control systems; a rich exchange of information, providing the \\
opportunity for organizational learning and possibly discovering both potential \\
risks and opportunities [9].
\end{tabular}

Triple Bottom Line (TBL)

An accounting framework that goes "beyond the traditional measures of profits, return on investment, and shareholder value to include environmental and social dimensions. (... .) The TBL dimensions are also commonly called the three Ps: people, planet and profit" [14] (p. 4). Also known by the abbreviations PPP, 3BL, or 3Ps (among other colloquial terms) but also often used interchangeably with Corporate Social Responsibility (CSR).

\begin{tabular}{ll}
\hline People & $\begin{array}{l}\text { Also referred to as equity or the social element. This concerns the human capital } \\
\text { and labor practices as well as attention being paid to (local) communities that in } \\
\text { some way are stakeholders in the organization's activities. }\end{array}$ \\
\hline Planet & $\begin{array}{l}\text { Also referred to as environment. This concerns for instance the ecological } \\
\text { footprint of a company, as well as efforts in sustainable product design and } \\
\text { recycling. }\end{array}$ \\
\hline Profit & $\begin{array}{l}\text { Also referred to as economy. This concerns the economic value but within a } \\
\text { broader perspective also the economic impact of an organization in general. }\end{array}$ \\
\hline $\begin{array}{l}\text { Corporate Social } \\
\text { Responsibility (CSR) }\end{array}$ & $\begin{array}{l}\text { "Corporate Social Responsibility is the voluntary act of companies to integrate } \\
\text { social and environmental interests into their business approaches, to contribute to } \\
\text { sustainable development and to be accountable for their impact on the } \\
\text { environment and society" [54]. }\end{array}$ \\
\hline $\begin{array}{l}\text { Supply chain } \\
\text { responsibility (SCR) }\end{array}$ & Basically CSR but applied holistically to a complete supply chain [12]. \\
\hline
\end{tabular}


Table 3. Cont.

\begin{tabular}{ll}
\hline Stakeholders & $\begin{array}{l}\text { Anyone who has a stake in the organization's activities, so anyone with an } \\
\text { interest in or influenced by said organization. This includes, but is not limited to: } \\
\text { employees, customers, suppliers, and end-users of the product. }\end{array}$ \\
\hline Shareholders & $\begin{array}{l}\text { Also known as stockholder, someone who owns a share of an organization. Their } \\
\text { financial benefits are dependent on the success of the organization. They } \\
\text { therefore have a legitimate claim on influence on the organization. Shareholders } \\
\text { are also stakeholders. }\end{array}$ \\
\hline Chain director & $\begin{array}{l}\text { The organization taking the lead in managing the supply chain as a whole, usually } \\
\text { the company with most power in the supply chain, with power being derived } \\
\text { from factors like market share and uniqueness of product or service [11] (p. 299). }\end{array}$ \\
\hline
\end{tabular}

Following the operationalization of constructs, an interview guideline was developed, based on the research reported by Andersen and Skjoett-Larsen [55] and Grimm, Hofstetter and Sarkis [56]. Because of the semi-structured approach and the explorative nature of the research the guideline was primarily used as such, rather than a questionnaire. This approach allowed for ample possibility for the interviewees to elaborate in their answers and provide relevant information. The theories provide many (technical) scientific terms and synonyms, and these had therefore been put in more generic or common terms in the questions to avoid confusion on semantics during the interview.

The interview guideline first covers the topic of organizational culture, in search of the organizations' stance on both the TBL and sustainability, as well as on general management and control. After that it shifts to SSCM and supplier interaction. The questions contain checks for Simons' different levers of control [9], the verification of a presence of a (strong) mission and vision concerning the TBL within the organization as well as in the supply chain, and inquiries into what is observed in practice of the efforts in control and governance regarding the suppliers. The questions help test the idea that, as a holistic view for (sustainable) supply chain management is deemed necessary [1], extension of organizational control and governance efforts would benefit the TBL. The interview guidelines are presented in Appendix A.

\subsection{Data Analysis, Reliability and Validity}

The interviews lasted from about half an hour to around an hour each, and were recorded in order to allow detailed transcription. Following the approach of theoretical thematic analysis, data analysis consisted of six steps $[57,58]$. First, all interviews were transcribed, which helps researchers to familiarize with the data. Second, transcripts were analyzed with QDA Miner, which is data analysis software that is especially suitable for managing, coding and analyzing qualitative data. In this study QDA Miner was used to facilitate a deductive approach. A deductive approach was chosen because of the specific scope of our study: the LOC framework. Thus, coding of the raw data followed the constructed glossary of relevant terminology, as derived from the operationalization of the central constructs of our study. Coding the data helped in structuring the subjective and very open conversations with the different respondents to line up with the chosen theoretical frameworks of this research. Third, relevant themes were identified, as well as (possible) connections between the themes. Fourth, the themes identified were reviewed and further refined, in order to determine whether the LOC discussed in organizational context were also applied (or applicable) in supply chain context. Fifth, a refined thematic map was constructed, in order to provide an overview of themes, as well as possible connections. This map is presented in Figure 1, providing an overview of themes related to LOC in supply chain context. In the sixth and final step, results of the data analysis are reported and placed into the context of the existing body of knowledge. 


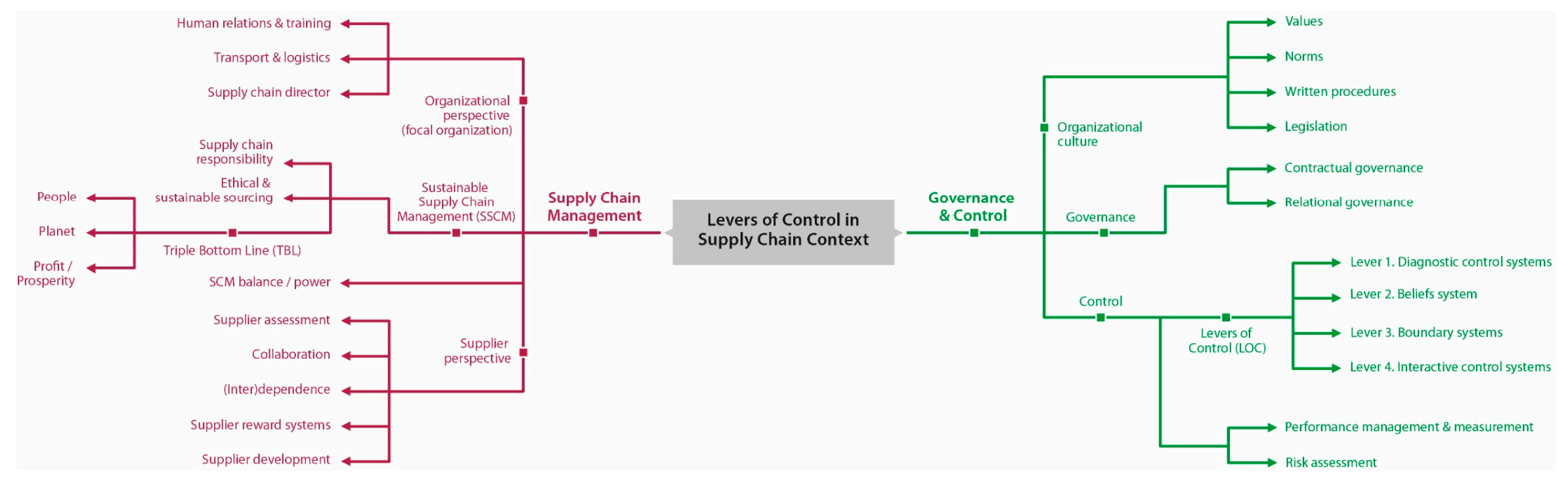

Figure 1. Thematic map: levers of control in supply chain context. 
Several measures and steps have been taken to enhance the validity and reliability of this study. The external validity is safeguarded by ensuring that our case study pertains to a multinational that is representative of other organizations that deal with the topic of the research. Our case can be viewed as a generalization since other comparable organizations (in size and structure), though possibly in different markets or types of business, are likely to run into the same pressures and challenges surrounding this topic. Although the sample for this research may only consist of a single company, our methodology allows for the research to be repeated within other organizations.

Internal validity is ensured by following three procedural guidelines recommended by Gibbert et al. [59] and Gibbert and Ruigrok [60] for undertaking rigorous case study research. First, we conducted a thorough literature review, grounding the study in past scientific research and placing the different elements of the thesis into perspective. A careful selection of relevant theories has been made to be considered in this research. Second, by using pattern matching, we have compared empirically observed patterns with patterns established in prior research from different contexts [61]. Third, we employed theory triangulation by using different bodies of literature to guide our data gathering [60]. This procedure allowed us to verify our findings from a multitude of perspectives [49].

Consequently, to warrant construct validity, we adopted the following strategies, closely following recommendations by Gibbert and Ruigrok [60]. First, we performed data triangulation by using various other sources besides the interviews, including policy documents and organizational performance reports of internal and external assessments. Furthermore, interviews have been executed across several relevant divisions of the organization, to gain a holistic perspective. Second, we established a clear chain of evidence that allows other researchers to reconstruct our analysis. Among others, the interviews are held on the basis of the guideline that has been specifically compiled and operationalized on the basis of existing scientific research. The interview guideline is rooted in the research question and corresponding literature study, and the responses are coded and analyzed on that basis. The interview guideline and results of the coding process can be found in the Appendix A and in Figure 1, respectively.

\section{Results}

\subsection{Triple Bottom Line Tradeoffs}

After the introduction of this study and its research objectives at the start of the interviews, one of the interviewees immediately said "Good, this is a big deal". The case organization has a strong presence of the TBL in their mission, policies and company structures. In all of the interviews it was clear that the profit bottom line is leading. The general consensus among interviewees was clear: "you can close down your factories if you don't make profit". One interviewee from the procurement department went as far as to say that profit and quality came first, with the rest of the factors following at a distance.

Working with the TBL proved to be a question of finding the right balance. An example on a smaller scale: The facility manager of a site that was visited had the desire to switch to LED lighting for environmental and long term cost benefits. However, a switch to LED lighting required investing in different light fixtures and this prolonged the payback time. It was unsure whether the firm would stay at this particular site long enough to payback the investments. If the investment would have been for a brand new building, then the firm would have proceeded with the LED option, according to a colleague from the financial department. The facility manager pointed out other benefits such as providing better light for the employees, yet this was discarded by the site leadership, because these potential benefits were difficult to quantify. The payback period remained crucial in the decision, showing the profit dimension to be the decisive factor.

On a bigger scale, the organization has a global sustainability coordinator, who is in charge of tracking all sustainability projects as well as all efforts in reducing energy consumption for their dozens of plants around the world. The focus is "more on the manufacturing sites as they are a bigger consumer compared to the offices". On both the local and global levels it was a conscious choice to go 
with (partially) green energy despite the large investment, showing that although profit is important, it is not the only factor.

With regard to sourcing, the case indicated the following. Where local sourcing is beneficial for the local community and reduces transport costs, centralized sourcing often involves cheaper production as a result of economies of scale. While moving mass production to a low wage country seems financially attractive, transport costs will increase. However, intensification of transport will also entail environmental costs. Mass production in low wage countries may generate social costs. The question is whether these environmental and social costs are part of the equation. The nature of multinational corporations induces globalization, and the nature of its business attracts stakeholders. Being a company on the stock market means having shareholders expectations to live up to. Shareholders increasingly value the environmental and social image of a company, which means that economic gains follow from investments that benefit people and planet aspects.

In part because of external pressures, the company puts in effort with regard to the planet bottom line by aiming for a sustainable method of operations. This development was illustrated in the interviews: "with sustainable operations, now we need to prove not only that we are a good company to work or things like that, but that you operate very well with subcontractors, that you don't cause any pollution in the world, that you reduce energy and gas consumption; This is now more or less normal life. Every company needs to prove this now. To be a big company [ . . ] at the stock exchange in New York, we need to add this flavor". In other words, it is expected from the company to correctly address environmental and social aspects of business operations, and being on the stock exchange makes this expectation become a necessity in regards to the financial aspect.

\subsection{Levers of Control}

Simons [9] provided managers with a framework of levers that can be used to control employees. The first lever of the diagnostic control system concerns the more technical approach of performance measurement practices. This can often be seen in the use of targets and bonuses but can also be interpreted as procedures that need to be followed, as diverting means punishment. Several interviewees stated that a high number of written procedures was unavoidable with a multinational organization of this size and that it improved consistence and continuity throughout the organization. Compliance to environmental standards and a possible bonus for a plant's waste reduction (so for the environmental bottom line but with a measurable performance indicator) were mentioned as examples of this lever, but for buyers in the procurement department, profit still takes the lead over planet in the setting of targets.

Across organizational boundaries, this lever can be recognized in procedures for supplier selection: specific TBL demands can be a part of this, with a people element like child labor being an example of an obvious disqualifier. The case organization had a document that clearly outlined these expectations for their supplying organizations and one such requirement is that their suppliers have something similar for their own suppliers, consistent with the expectations of the case organization. Through this approach, the TBL efforts of the focal organization cross another organizational boundary and reach further in the supply chain towards second and third tier suppliers.

There is also a strict process of supplier assessment. Different suppliers will get different levels of assessment, depending on the importance of the item being supplied. Additionally, one interviewee told that if a supplier shows a level of performance that is below the agreed level, or if that supplier shows a quality issue or issue with environmental or social aspects, then the assessment of said supplier will be increased the next time around, which could lead to the conclusion to end the cooperation with this supplier.

The second lever is a beliefs system. Within the case organization there was a clear vision and mission statement regarding the TBL and this was visible in all of the company's official documents. In order to make sure that everyone within the organization is on the same page, training on the code of conduct is mandatory and a small part of employee assessments. One interviewee said he felt like 
most people would have forgotten the contents of the documents within hours after reading but also felt that the values were so deeply integrated into the work that everyone still works in line with them. Others echoed this sentiment, and all interviewees felt that in some way or form the values have been internalized; when it comes to the ethics of the values, all deemed it normal and common sense to act that way.

Leadership has its place in the organization's beliefs system: at multiple locations on the factory site and on the back of the keycards, the company mission statement can be found, signed by the CEO. In weekly mails and at townhall meetings the top layers will always pay some attention to the topic of sustainability. These actions in the sense of leading by example in emphasizing the importance of the topic contribute to this lever.

The documents with expectations for supplying organizations are not on all points as enforceable (which would make it fit more with the first LOC), but it sets expectations for how the organization's beliefs system should be interpreted by suppliers. The case organization rarely provided an accompanying training for suppliers on these subjects, but it was also mentioned as something they would like to further develop in the future.

The third lever is a boundary system and can be difficult to recognize: the strictness and level of detail of a compliance rule could place methods of control in the category of the diagnostic control system or this category of the boundary system. Regulations, both internal and external, for example, dictating maximum levels of certain chemical components, would fall in the latter category. Another way of applying to TBL goals further than the bare minimum was mentioned in the interviews: "A lot of times people use their discretionary time and discretionary efforts to push these types of projects along, and they are passionate about these things". The company also offers possibilities for social and environmental projects, and employees use them, even though neither are required to do this. One example mentioned during the interviews was the initiative to go to a site in Africa for three weeks (on the boss's time), in order to give local training or help set up a new plant. This concerns a boundary system that more explicitly focusses on the people and planet bottom lines, and which is stimulated by the strong presence of the beliefs system.

Giving suppliers freedom and discretionary room can seem as actions that are risky and could negatively influence profit, but after proper application of the first two levers, the supplier can become more of a collaborative partner and join in working towards all the goals of the supply chain director. The case organization has a recognition program for such effort by suppliers to stimulate them.

The fourth and final lever is the interactive control system. All interviewees mentioned ways of interaction that would fit within this lever, which included more informal ways, with some of them noting that it was for a big part the qualities and personalities of their leadership team that enabled this. If an employee sees a chance or opportunity, there are ways to communicate this; a side note that was made to this was that some of the actions might take a while in a big and regulated company, which often prevents quick responses as an idea would have to travel up the hierarchy. For possible threats, however, special channels are available in the case organization that lead straight to the CEO. The company's natural state of risk aversion has a role in shaping this system.

In the supply chain other stakeholders are included as well, shown in the example of lever 4 given by an interviewee: "On occasion we bring in different customers to talk about what their issues are. We bring in suppliers on a supplier forum to talk about industry issues, our pressing needs, and how the industry is changing and what we can do to be more collaborative and help each other be more successful". This shows that this specific lever is being used to look at the bigger picture of the full supply chain, including both consumers and supplier perspectives.

Interviewees acknowledge the fact that trying to be sustainable as part of a supply chain requires putting in effort across organizational boundaries but also that this should go in both directions: "You have to work together with suppliers, otherwise this is impossible to achieve. For example, the supplier might use certain chemicals, which may prove no problem for their own goals. [We] will in those cases ask them to look into alterations". Going in the opposite direction are the possible suggestions and 
chances the suppliers communicate towards the supply chain director, so that both can benefit; this can be the case on all bottom lines.

The large number of suppliers a multinational has worldwide provides a challenge for supplier governance, limiting the level of interaction possible across the full field. "We can't do that, but we'd like to; we'd like to engage with every supplier to ensure their compliance with our supplier governance requirements". Because of these limitations, it often only concerns key, strategic and/or preferred suppliers. A related sentiment that was heard in a number of the interviews is that the quality of interaction and collaboration is good but still not as mature as they would like it to be. "There is usually a crisis or some kind of initiating event that causes us to collaborate, and I just wish we had the manpower to do more". Manpower can be translated into cost, showing the balance of the bottom lines again leaning over towards profit.

\section{Discussion}

This case study illustrates the claim that "economic prosperity, environmental quality and social justice will increasingly become the driving forces for transnational corporations" [62] (p. 281). However, the new conditions mentioned by Child [3] impact this TBL in several ways. Globalization leads to increasingly complex and uncertain environmental and ethical (social) challenges of MNCs' supply chains [1]. Increasing logistics movements are typically accompanied by a higher impact on the environment. Local sourcing in support of local business will benefit the social bottom line. Growing consumer awareness towards unethical behavior in supply chain context might encourage companies to back- or nearshore parts of their production processes [34]. The greater number of suppliers needed and fewer benefits derived from economies of scale could in turn lead to higher costs. It is clear that, in order to integrate sustainability in MNC context, focus on the supply chain context is inevitable [63].

This provides new tradeoffs, but examples from this research showed that those are not necessarily balanced, which strengthens the call for holistic and critical approaches with regard to the TBL $[1,15,54]$. For example, the results show that, under influence of international ethical standards, a focus on the social bottom line is a "need to have" in order to prevent social misconduct. The profit dimension needs to be focused on for the survival of the company, which reflects shareholder interest. The environmental focus, however, is classified as "nice to have" but not a priority in the case company. This might partly be explained by the profile of the MNC, which is active in medical technology, in which quality of products might outweigh environmental concerns. However, this research also showed that efforts towards the planet bottom line positively influence the company's attractiveness and (consequently) profitability in the long term, so the timeframe considered is relevant for the balances in tradeoffs. It might also be an illustration of strategic long term thinking of MNCs, in which investing in the planet bottom line is believed to deliver long term profits $[25,63,64]$.

Table 4 provides an overview of LOC as observed at organizational and supply chain level. All four LOC can be used simultaneously, and it is the balance and integration of the different levers that lets them stimulate and reinforce each other. This account of harmony between the levers leading to increased effectiveness fits with the research by Cao and Lumineau [41]. They showed that contractual and relational governance are complementary and thrive on interplay. With the levers crossing the organizational boundaries in the supply chain, the case organization showed to have a large number of long-term relations where relational governance and the "softer" levers have had more opportunity to develop and where the relation had developed more towards collaboration. With other relations however, the different levers made sure that the purchasing department was well equipped to assess suppliers based on the TBL principles (so internal application of the levers), while the contracts are supplemented by using the "expectations for suppliers" and training. This application of the LOC in the upstream supply chain might facilitate intra- and inter-firm collaboration [65]. Several gaps in supply chain governance mentioned by Boström et al. [66] are filled because of the use of multiple levers: The compliance and implementation gap is reduced by the diagnostic control systems, the information and knowledge gap by the beliefs system, and the communication gap by the interactive 
control system. While it is of course true that not every link of a supply chain could possibly be the more powerful one influencing the others, it should also be taken into account that the pressures to act along TBL principles affect all links differently. Not all organizations will have the same commitment to sustainability principles. Larger organizations, which are more in the spotlight than the smaller ones, are expected to actively work on their CSR and Supply Chain Responsibility (SCR) [12]. At the same time, however, a supply chain director might try to enforce its standards on organizations that are not capable to deal with them, be it through practical differences as for instance size or cultural differences, as the popular saying (often attributed to Peter Drucker) goes: Culture eats strategy for breakfast. Simply applying the first lever of control would not work. Collaboration with the smaller organizations (through the use of the other LOC), though possibly costly in time and money and thus becoming a TBL tradeoff, should help the smaller suppliers join in the progress, while being both beneficial to the supply base of the larger organization as well as to the performance of the supply chain as a whole. Focal organizations might include social performance metrics and standards in order to enhance their performance [67]. A possible additional connection between organizational tools and supply chain context, might be the widespread adoption and use of ISO standard and certification. In order to encourage this, ISO standards used in the organization need to be connected to integrated supply chain management systems [68]. The fact that SME's (small and medium-sized enterprises) also experience these new conditions for organizations to adopt environmental strategies is discussed by Testa et al. [69]. They approach it from a slightly different angle, looking at the life cycle assessment (LCA) of a product, which involves the full supply chain of a product. The questions answered by their research concern the position and resources needed to keep up with the pressure for efforts for the Planet bottom line. The demands in the supply chain and its downstream links require action from the SME's. They collaborate within the same cluster with competitors and with local stakeholders and are helped by enablers like a chamber of commerce in developing environmental management capabilities (EMC). Access to data is most important in their conclusions when it comes to discussing the supply chain, but collaboration with larger buyers (a possible supply chain director) however is only briefly mentioned.

Findings of this study show that a supply chain director should use a balanced combination of control and governance practices, which is achievable through the application of the different levers of the LOC framework across the supply chain. This is in line with Golini et al. [70] who show that relational and captive governance work better than market governance when it comes to the concept of "upgrading" being applied to functional, social and environmental dimensions. Their research concerned a lead firm in a global value chain, very similar to the supply chain director in the supply chain in our study, and showed that social and environmental upgrading follow similar patterns as economic upgrading when relational and captive governance are present.

Cheng et al. [71] discuss that within the context of Green Public Procurement, there are difficulties in implementation and uptake of those policies: " ... significant challenges, including lacking environmental knowledge and awareness, organizational goals and structure, political commitment, and financial issues" (p. 776). Despite the public sector being different on many levels, the issues mentioned with their procurement are blamed on a lack of guidance (which can be read as control and governance mechanisms) to remedy them. Furthermore, the article discusses research into the attitudes of suppliers as well, concluding that environmental standards from policy alone are not enough to activate them to do their SCR part. While it cannot be stated as fact, this does lead to theorize that GPP would benefit greatly from being executed through the LOC, both within the organization as well as in their supply chain. In the brief summary of issues mentioned above, a missing diagnostic control system can be seen in the lack of organizational goals, and lacking knowledge and awareness can be the result of not having a beliefs system. The conclusions of the article do not discuss the full LOC and mainly suggest the need for environmental criteria to be compulsory, and the given fact that is has been put into legislation puts it closer to compliance than commitment and closer to the TBL interpretation as an accounting tool that Elkington dreaded. Additionally, the research also shows that 
even in the public sector where profit is not usually an organizational goal, the financial bottom line appears to have a strong influence in the TBL balance.

Table 4. Levers of control (LOC) at organizational and supply chain level.

\begin{tabular}{|c|c|c|}
\hline Levers/Mechanisms & Organization & Supply Chain \\
\hline $\begin{array}{l}\text { Lever 1: } \\
\text { Diagnostic control systems }\end{array}$ & $\begin{array}{l}\text { Triple Bottom Line (TBL) part } \\
\text { of performance management } \\
\text { (however: bonus structure not } \\
\text { (explicitly) considers planet } \\
\text { and people dimensions) } \\
\text { - Intensive use of procedures. }\end{array}$ & $\begin{array}{l}\text { - } \\
\text { - } \\
\text { selection procedures. } \\
\text { TBL elements in contracts and } \\
\text { production specifications. } \\
\text { - } \quad \begin{array}{l}\text { Regular assessments of } \\
\text { supplier base. }\end{array}\end{array}$ \\
\hline $\begin{array}{l}\text { Lever 2: } \\
\text { Beliefs systems }\end{array}$ & $\begin{array}{l}\text { Mission and vision are all } \\
\text { around on sites, e.g., posters, } \\
\text { keycards. Internalization of } \\
\text { values: documentation and } \\
\text { training on the company's TBL } \\
\text { efforts, townhall meetings, } \\
\text { videos by management on } \\
\text { the subject. }\end{array}$ & $\begin{array}{l}\text { - TBL vision in documentation } \\
\text { ("Expectations for suppliers"). } \\
\text { - Training of suppliers (but } \\
\text { rarely used). }\end{array}$ \\
\hline $\begin{array}{l}\text { Lever 3: } \\
\text { Boundary systems }\end{array}$ & $\begin{array}{l}\text { Employees give training at } \\
\text { sites abroad. } \\
\text { Employees can nominate } \\
\text { candidates for the company's } \\
\text { supplier awards. } \\
\text { - Procedures for compliance } \\
\text { reasons function as } \\
\text { minimum requirements. } \\
\text { Environmental improvement is } \\
\text { stimulated (if no vast increase } \\
\text { in cost or loss of quality). }\end{array}$ & $\begin{array}{l}\text { The company rewards } \\
\text { suppliers with awards. } \\
\text { Award for sustainability. }\end{array}$ \\
\hline $\begin{array}{l}\text { Lever 4: } \\
\text { Interactive control systems }\end{array}$ & $\begin{array}{l}\text { Informal interactivity } \\
\text { (approachability of } \\
\text { management, leadership). } \\
\text { Technical support (reporting } \\
\text { possible threats directly to the } \\
\text { top management through } \\
\text { special channels). }\end{array}$ & $\begin{array}{l}\text { Potential is recognized but } \\
\text { rarely used so far. } \\
\text { Higher level of collaboration } \\
\text { would entail investment but } \\
\text { is desirable. } \\
\text { - Key suppliers involved in early } \\
\text { stages of product development. }\end{array}$ \\
\hline
\end{tabular}

Focusing on the TBL approach might lead to the wish to develop supplemental and contextual frameworks in combination with the TBL to gain more insight into the supply chain. For example, the people bottom line is broad, and there is a difference in the levels of influence the organization has on its customers, employees, and suppliers. It reminds us of the possibility mentioned by Hacking and Guthrie [16] for expanding the TBL by dividing it in more categories, which was also criticized by themselves, reasoning that the thinner slices this would bring would not bring an increase in insight. This can also be linked to the commentary by Norman and Macdonald [7] and their argument that the value of the TBL approach is lacking because of the suitability for measurement of the people and planet bottom lines: the bigger the scope of the TBL intentions, the more difficult it will be to be concise and SMART in formulating the goals. Measuring the impact on the environment is difficult, but measuring the reduction of the use of a certain polluting material in production is more doable and something you can make contractual agreements on with suppliers. Going for a further division of the TBL elements within the three categories of people, planet and profit might not bring more information, but it could help in making it more measurable and controllable as certain subtopics 
are more concise than others. This would be a similar approach as the one by Bai and Sarkis [72] for making the TBL part of supplier selection, which was also present in the case study organization.

\section{Conclusions}

This study focused on how the use of control and governance practices in the context of SSCM influences the TBL performance of a multinational organization. The extant literature provided the notion that as a holistic view for supply chain is deemed necessary, an extension of organizational control and governance efforts would benefit the TBL. The three different elements of TBL, People, Planet and Profit, exist in a balance where profit will take priority over the others, showing it to be a new tradeoff for managers to deal with. Making money is a requirement for the existence and continuity of any profit organization, whereas the other bottom lines are not (yet). For a large multinational organization however, it is expected that attention is paid to social and environmental aspects of operations, which in turn could influence profitability as a result of how these aspects are valued in the market. Often these efforts will entail investments and hence increases costs. This makes TBL goalsetting a paradoxical practice.

The control and governance efforts that are used in MNCs can be framed using the LOC framework by Simons, showing the different practices being applied in different cases and contexts. Just as the TBL, the LOC interplay. The "softer" elements of TBL, i.e., People and Planet, are more feasible for an approach with a beliefs system, which in turn enforces the boundary and interactive control systems. As multinationals inevitably are part of supply chains, their challenge lies in bringing the social and environmental dimensions to the same level as the economic dimension for the entire supply chain. In order to be truly successful in all TBL dimensions on a supply chain level, the LOC can be applied across organizational boundaries, causing a "spill-over" effect upstream in their supply chain. Some TBL topics can be made measurable and a part of contracts with suppliers, but with fewer tangible elements, collaborative relations are preferred. The higher-level LOC may be aimed at instilling links of the supply chain with the supply chain director's TBL beliefs and building the boundaries and structural opportunities to act and collaborate upon those.

Our study has limitations. Most importantly, our sample included only employees from one large organization. Although this particular organization in its role as supply chain director can be considered representative for other similar organizations worldwide, the extent of generalizability of our results may be limited to large multinational organizations. Furthermore, our study looks at the topic from the perspective of this focal organization in its role as supply chain director. The viewpoint of suppliers as well as customers has only been derived from secondary sources, such as internal and external reports, briefings and policy documents. Further analyzing the role of stakeholders in the supply chain might add more perspectives to the use of LOC in supply chain context and is an important recommendation for further research.

The industry of the case organization also needs to be taken into account. The medical and pharmaceutical industry faces a multitude of rules and regulations that for instance dictate shipping requirements and limit options for recycling as it often concerns medical waste. Furthermore, globalized supply chains are vulnerable to disasters, the most recent example being the disruptive effect of COVID-19 on health care supply chains, resulting in shortages of medical equipment around the world. Within this context, more resilient supply chains are called for in order to cope with such disasters [73]. Future research may want to conduct a more extensive study, including organizations in other industries, sectors and of other sizes. Despite these limitations, this study shows the potential of the possible utilization of the complete set of LOC in a SSCM context and the value it could have for the performance of the organization and its supply chain, on the full TBL instead of just supply chain profitability, thereby surpassing limited views in which profit is superior to the other dimensions, and contributing to supply chain resilience.

Author Contributions: Conceptualization, J.d.H.-H. and W.L.; methodology, J.d.H.-H. and W.L.; validation, W.L.; formal analysis, J.d.H.-H. and W.L.; investigation, J.d.H.-H. and W.L.; data curation, J.d.H.-H. and W.L.; 
writing-Original draft preparation, J.d.H.-H., W.L., J.S. and M.C.J.C.; writing-Review and editing J.d.H.-H., W.L., J.S. and M.C.J.C.; visualization, J.d.H.-H. and W.L.; supervision, W.L., J.S. and M.C.J.C. All authors have read and agreed to the published version of the manuscript.

Funding: This research received no external funding.

Conflicts of Interest: The authors declare no conflict of interest.

\section{Appendix A}

Table A1. Interview guidelines.

\begin{tabular}{|c|c|c|}
\hline & Questions & Source \\
\hline \multicolumn{3}{|c|}{ Introduction: } \\
\hline 1 & Introduction researcher, study and research objectives & [56] \\
\hline 2 & Assuring confidentiality, informing about recording and transcription & [56] \\
\hline \multicolumn{3}{|c|}{ Facts about interviewee: } \\
\hline 3 & What is your position at [organization]? & [55] \\
\hline 4 & How many years have you been employed with [organization]? & [55] \\
\hline \multicolumn{3}{|c|}{ Organizational culture: } \\
\hline 5 & Does the organization rely much on written procedures, policies, etc.? & [55] \\
\hline 6 & $\begin{array}{l}\text { Does [organization] have a written set of values? Do you know what these values } \\
\text { are? How would you describe the traditions, values and norms at [organization]? } \\
\text { How do these values influence your daily work? }\end{array}$ & [55] \\
\hline 7 & $\begin{array}{l}\text { To what extent are environmental and social issues integrated into the various } \\
\text { functions within the organization? }\end{array}$ & [55] \\
\hline 8 & Have you received training on environmental and social topics? & [55] \\
\hline 9 & $\begin{array}{l}\text { How is employee performance measured? How are environmental and social } \\
\text { issues a part of performance appraisal? }\end{array}$ & [55] \\
\hline 10 & $\begin{array}{l}\text { How is the support/involvement of top management when it comes to these } \\
\text { sustainability requirements? }\end{array}$ & [55] \\
\hline 11 & $\begin{array}{l}\text { How would you describe interest/support from colleagues not directly involved } \\
\text { with these kinds of issues? }\end{array}$ & [55] \\
\hline \multicolumn{3}{|c|}{ Sustainable supply chain management and supplier interaction: } \\
\hline 12 & How many (first tier) suppliers do you have? & [56] \\
\hline 13 & What is the balance of power between the suppliers and [organization]? & [55] \\
\hline 14 & $\begin{array}{l}\text { What are the major social and environmental sustainability issues your firm is } \\
\text { facing with your supply chains? }\end{array}$ & [56] \\
\hline 15 & How would you describe you suppliers' social and environmental awareness? & [56] \\
\hline 16 & $\begin{array}{l}\text { For what reason and in which cases do you actively approach (sub-)suppliers } \\
\text { within the context of sustainability? Do suppliers approach you on the subject? }\end{array}$ & [56] \\
\hline 17 & What are your social and environmental requirements towards your suppliers? & [56] \\
\hline 18 & $\begin{array}{l}\text { How do you communicate your requirements to your suppliers? How do you } \\
\text { ensure that these requirements are correctly interpreted by your suppliers? How } \\
\text { much freedom do they get to do so on their own? }\end{array}$ & [56] \\
\hline 19 & $\begin{array}{l}\text { What kind of feedback has [organization] received from the suppliers concerning } \\
\text { the social and environmental requirements? }\end{array}$ & [55] \\
\hline
\end{tabular}


Table A1. Cont.

\begin{tabular}{|c|c|c|}
\hline & Questions & Source \\
\hline 20 & $\begin{array}{l}\text { When and how have the "[organization] expectations for suppliers" been } \\
\text { developed? What have been the considerations underlying the development of } \\
\text { these expectations? Has [organization] received external assistance for building up } \\
\text { these expectations? }\end{array}$ & [55] \\
\hline 21 & $\begin{array}{l}\text { To what extent is [organization] in dialogue with its stakeholders about its work on } \\
\text { supply chain social responsibility? }\end{array}$ & [55] \\
\hline 22 & Are these requirements measurable and verifiable? & [56] \\
\hline 23 & $\begin{array}{l}\text { What are the main drivers for your suppliers to comply with your issued } \\
\text { requirements? }\end{array}$ & [56] \\
\hline 24 & $\begin{array}{l}\text { Are the mission and vision, values and norms discussed with the suppliers? Are } \\
\text { they shared by them? }\end{array}$ & $\begin{array}{l}\text { Author's own } \\
\text { elaboration }\end{array}$ \\
\hline 25 & $\begin{array}{l}\text { To what extend do you feel the efforts for people and planet are genuine and } \\
\text { sincere? How do you think profit influences their efforts for people and planet? }\end{array}$ & $\begin{array}{l}\text { Author's own } \\
\text { elaboration }\end{array}$ \\
\hline 26 & $\begin{array}{l}\text { How do you control suppliers for compliance with your corporate sustainability } \\
\text { standards? What approaches do you use? (For example self-assessments, } \\
\text { certifications, audits, training, rewards, etc.) }\end{array}$ & [56] \\
\hline 27 & Do you train suppliers? & [56] \\
\hline 28 & $\begin{array}{l}\text { Do your suppliers supply to more organizations? Are you working together with } \\
\text { other firms to ensure compliance with corporate sustainability standards? }\end{array}$ & [56] \\
\hline 29 & Do you collaborate with suppliers expressly to pursue all three bottom lines? & $\begin{array}{l}\text { Author's own } \\
\text { elaboration, } \\
\text { based on [56] }\end{array}$ \\
\hline 30 & $\begin{array}{l}\text { What makes successful supplier management possible? What are the barriers? } \\
\text { What are the main challenges? }\end{array}$ & [56] \\
\hline 31 & $\begin{array}{l}\text { How do you see the role of actively managing your suppliers in the future? Would } \\
\text { you expect a further increase in attention for the triple bottom line? }\end{array}$ & [56] \\
\hline
\end{tabular}

\section{References}

1. Lambrechts, W. Ethical and Sustainable Sourcing: Towards Strategic and Holistic Sustainable Supply Chain Management. In Decent Work and Economic Growth. Encyclopedia of the UN Sustainable Development Goals; Leal Filho, W., Azul, A., Brandli, L., Özuyar, P., Wall, T., Eds.; Springer: Cham, Switzerland, 2020. Available online: https://link.springer.com/referenceworkentry/10.1007/978-3-319-71058-7_11-1 (accessed on 10 March 2020).

2. De Wit, M.; Meyer, R. Strategy Synthesis: Managing Strategy Paradoxes to Create Competitive Advantage, 3rd ed.; Cengage Learning EMEA: Andover, MA, USA, 2014.

3. Child, J. Organization: Contemporary Principles and Practice, 2nd ed.; John Wiley and Sons Ltd.: Hoboken, NJ, USA, 2015.

4. Gimenez, C.; Sierra, V. Sustainable Supply Chains: Governance Mechanisms to Greening Suppliers. J. Bus. Ethics 2012, 116, 189-203. [CrossRef]

5. Gimenez, C.; Tachizawa, E.M. Extending sustainability to suppliers: A systematic literature review. Supply Chain Manag. Int. J. 2012, 17, 531-543. [CrossRef]

6. Schmidt, C.G.; Foerstl, K.; Schaltenbrand, B. The Supply Chain Position Paradox: Green Practices and Firm Performance. J. Supply Chain Manag. 2016, 53, 3-25. [CrossRef]

7. Norman, W.; Macdonald, C. Getting to the Bottom of "Triple Bottom Line". Bus. Ethics Q. 2004, 14, $243-262$. [CrossRef]

8. Bhardwaj, B.R. Role of green policy on sustainable supply chain management. Benchmarking Int. J. 2016, 23, 456-468. [CrossRef]

9. Simons, R. Control in an age of empowerment. Harv. Bus. Rev. 1995, 73, 80-88.

10. Hoque, Z.; Chia, M. Competitive forces and the levers of control framework in a manufacturing setting: A tale of a multinational subsidiary. Qual. Res. Account. Manag. 2012, 9, 123-145. [CrossRef] 
11. Gelderman, C.J.; Albronda, B. Professioneel Inkopen, 5th ed.; Noordhoff Uitgevers: Groningen, The Netherlands, 2017.

12. Spence, L.; Bourlakis, M. The evolution from corporate social responsibility to supply chain responsibility: The case of Waitrose. Supply Chain Manag. Int. J. 2009, 14, 291-302. [CrossRef]

13. Elkington, J. Cannibals with Forks: The Triple Bottom Line of Twentieth Century Business; Capstone: Oxford, UK, 1997.

14. Slaper, T.F.; Hall, T.J. The triple bottom line: What is it and how does it work. Indiana Bus. Rev. 2011, 86, 4-8.

15. Elkington, J. 25 years ago I coined the phrase “Triple Bottom Line". Here's Why it Is time to Rethink it. Harvard Business Review, 2018. Available online: https://hbr.org/2018/06/25-years-ago-i-coined-the-phrasetriple-bottom-line-heres-why-im-giving-up-on-it (accessed on 10 December 2019).

16. Hacking, T.; Guthrie, P. A framework for clarifying the meaning of Triple Bottom-Line, Integrated, and Sustainability Assessment. Environ. Impact Assess. Rev. 2008, 28, 73-89. [CrossRef]

17. Sridhar, K.; Jones, G. The three fundamental criticisms of the Triple Bottom Line approach: An empirical study to link sustainability reports in companies based in the Asia-Pacific region and TBL shortcomings. Asian J. Bus. Ethics 2012, 2, 91-111. [CrossRef]

18. Carter, C.R.; Rogers, D.S. A framework of sustainable supply chain management: Moving toward new theory. Int. J. Phys. Distrib. Logist. Manag. 2008, 38, 360-387. [CrossRef]

19. Pagell, M.; Shevchenko, A. Why Research in Sustainable Supply Chain Management Should Have no Future. J. Supply Chain Manag. 2014, 50, 44-55. [CrossRef]

20. Pagell, M.; Wu, Z. building A more complete theory of sustainable supply chain management using case studies of 10 exemplars. J. Supply Chain Manag. 2009, 45, 37-56. [CrossRef]

21. Ahi, P.; Searcy, C. A comparative literature analysis of definitions for green and sustainable supply chain management. J. Clean. Prod. 2013, 52, 329-341. [CrossRef]

22. Ahi, P.; Searcy, C. An analysis of metrics used to measure performance in green and sustainable supply chains. J. Clean. Prod. 2015, 86, 360-377. [CrossRef]

23. Seuring, S.; Müller, M. From a literature review to a conceptual framework for sustainable supply chain management. J. Clean. Prod. 2008, 16, 1699-1710. [CrossRef]

24. Guide, V.D.R.; Jayaraman, V.; Linton, J. Building contingency planning for closed-loop supply chains with product recovery. J. Oper. Manag. 2002, 21, 259-279. [CrossRef]

25. Schenkel, M.; Krikke, H.; Caniëls, M.C.; Lambrechts, W. Vicious cycles that hinder value creation in closed loop supply chains: Experiences from the field. J. Clean. Prod. 2019, 223, 278-288. [CrossRef]

26. Krikke, H. Value Creation in a Circular Economy: An Interdisciplinary Approach. In Decent Work and Economic Growth. Encyclopedia of the UN Sustainable Development Goals; Leal Filho, W., Azul, A., Brandli, L., Özuyar, P., Wall, T., Eds.; Springer: Cham, Switzerland, 2020. Available online: https://link.springer.com/ referenceworkentry/10.1007/978-3-319-71058-7_5-1 (accessed on 2 February 2020).

27. Shaharudin, M.S.; Fernando, Y.; Jabbour, C.J.C.; Sroufe, R.; Jasmi, M.F.A.; Jasmi, F. Past, present, and future low carbon supply chain management: A content review using social network analysis. J. Clean. Prod. 2019, 218, 629-643. [CrossRef]

28. Seuring, S.; Gold, S. Sustainability management beyond corporate boundaries: From stakeholders to performance. J. Clean. Prod. 2013, 56, 1-6. [CrossRef]

29. Cruz, J.M. The impact of corporate social responsibility in supply chain management: Multicriteria decision-making approach. Decis. Support Syst. 2009, 48, 224-236. [CrossRef]

30. Gold, S.; Hahn, R.; Seuring, S. Sustainable supply chain management in "Base of the Pyramid" food projects-A path to triple bottom line approaches for multinationals? Int. Bus. Rev. 2013, 22, 784-799. [CrossRef]

31. Quarshie, A.M.; Salmi, A.; Leuschner, R. Sustainability and corporate social responsibility in supply chains: The state of research in supply chain management and business ethics journals. J. Purch. Supply Manag. 2016, 22, 82-97. [CrossRef]

32. De Haan, J.A.; Sacristán-Díaz, M. Measuring performance at the supply chain level: The role of the chain director. Wpom Work. Pap. Oper. Manag. 2016, 7, 1. [CrossRef]

33. Foerstl, K.; Azadegan, A.; Leppelt, T.; Hartmann, E. Drivers of Supplier Sustainability: Moving Beyond Compliance to Commitment. J. Supply Chain Manag. 2014, 51, 67-92. [CrossRef] 
34. Veit, C.; Lambrechts, W.; Quintens, L.; Semeijn, J. The Impact of Sustainable Sourcing on Customer Perceptions: Association by Guilt from Scandals in Local vs. Offshore Sourcing Countries. Sustainability 2018, 10, 2519. [CrossRef]

35. Agan, Y.; Kuzey, C.; Acar, M.F.; Açıkgöz, A. The relationships between corporate social responsibility, environmental supplier development, and firm performance. J. Clean. Prod. 2016, 112, 1872-1881. [CrossRef]

36. Farneti, F.; Guthrie, J. Sustainability reporting by Australian public sector organisations: Why they report. Acc. Forum 2009, 33, 89-98. [CrossRef]

37. Kumar, D.T.; Palaniappan, M.; Kannan, D.; Shankar, M. Analyzing the CSR issues behind the supplier selection process using ISM approach. Resour. Conserv. Recycl. 2014, 92, 268-278. [CrossRef]

38. Carbone, V.; Moatti, V.; Wood, C.H. Diffusion of Sustainable Supply Chain Management: Toward a Conceptual Framework. Supply Chain Forum Int. J. 2012, 13, 26-39. [CrossRef]

39. Scheiber, F. Dressing up for Diffusion: Codes of Conduct in the German Textile and Apparel Industry, 1997-2010. J. Bus. Ethics 2013, 126, 559-580. [CrossRef]

40. Bartczek, S. The Impact of Corporate Buyers on Corporate Social Responsibility in Textile Supply Chains. Ph.D. Thesis, Kassel University Press, Kassel, Germany, 2018.

41. Cao, Z.; Lumineau, F. Revisiting the interplay between contractual and relational governance: A qualitative and meta-analytic investigation. J. Oper. Manag. 2014, 33, 15-42. [CrossRef]

42. Caniëls, M.C.J.; Gelderman, C.J.; Vermeulen, N.P. The interplay of governance mechanisms in complex procurement projects. J. Purch. Supply Manag. 2012, 18, 113-121. [CrossRef]

43. Bruno, T.; Gelderman, C.J.; Lambrechts, W.; Semeijn, J. The promise of Best Value Procurement: Governance and (in)stability of specifications within an innovative biogas project. J. Clean. Prod. 2018, 172, 1465-1475. [CrossRef]

44. Gelderman, C.J.; Semeijn, J.; de Bruijn, A. Dynamics of service definitions-An explorative case study of the purchasing process of professional ICT-services. J. Purch. Supply Manag. 2015, 21, 220-227. [CrossRef]

45. Merchant, K.A.; van der Stede, W.A. Management Control Systems; Performance Measurement, Evaluation and Incentives, 3rd ed.; Pearson education: Harlow, UK, 2012.

46. Kruis, A.-M.; Speklé, R.; Widener, S.K. The Levers of Control Framework: An exploratory analysis of balance. Manag. Acc. Res. 2016, 32, 27-44. [CrossRef]

47. Gond, J.-P.; Grubnic, S.; Herzig, C.; Moon, J. Configuring management control systems: Theorizing the integration of strategy and sustainability. Manag. Acc. Res. 2012, 23, 205-223. [CrossRef]

48. Tessier, S.; Otley, D. A conceptual development of Simons' Levers of Control framework. Manag. Acc. Res. 2012, 23, 171-185. [CrossRef]

49. Yin, R.K. Case Study Research: Design and Methods; SAGE Publications: Thousand Oaks, CA, USA, 2009.

50. Anthony, R.N.; Govindarajan, J. Management Control Systems, 12th ed.; McGraw-Hill/Irwin: New York, NY, USA, 2007.

51. Burns, J.; Quinn, M.; Warren, L.; Oliveira, J. Management Accounting; McGraw-Hill Education: Maidenhead Berkshire, UK, 2013.

52. Bevir, M. Governance: A very Short Introduction; Oxford University Press: Oxford, UK, 2012.

53. Kleindorfer, P.; Singhal, J.; Van Wassenhove, L.N. Sustainable Operations Management. Prod. Oper. Manag. 2009, 14, 482-492. [CrossRef]

54. Molderez, I. Corporate Social Responsibility and the Sustainable Development Goals (SDGs). In Decent Work and Economic Growth. Encyclopedia of the UN Sustainable Development Goals; Leal Filho, W., Azul, A., Brandli, L., Özuyar, P., Wall, T., Eds.; Springer: Cham, Switzerland, 2020. Available online: https: //link.springer.com/referenceworkentry/10.1007/978-3-319-71058-7_7-1 (accessed on 2 April 2020).

55. Andersen, M.; Skjoett-Larsen, T. Corporate social responsibility in global supply chains. Supply Chain Manag. Int. J. 2009, 14, 75-86. [CrossRef]

56. Grimm, J.H.; Hofstetter, J.; Sarkis, J. Exploring sub-suppliers' compliance with corporate sustainability standards. J. Clean. Prod. 2016, 112, 1971-1984. [CrossRef]

57. Braun, V.; Clarke, V. Using thematic analysis in psychology. Qual. Res. Psychol. 2006, 3, 77-101. [CrossRef]

58. Nowell, L.S.; Norris, J.M.; White, D.E.; Moules, N.J. Thematic analysis: Striving to meet the trustworthiness criteria. Int. J. Qual. Methods 2017, 16, 1-13. [CrossRef]

59. Gibbert, M.; Ruigrok, W.; Wicki, B. What passes as a rigorous case study? Strat. Manag. J. 2008, 29, 1465-1474. [CrossRef] 
60. Gibbert, M.; Ruigrok, W. The "What" and "How" of Case Study Rigor: Three Strategies Based on Published Work. Organ. Res. Methods 2010, 13, 710-737. [CrossRef]

61. Eisenhardt, K.M. Building theories from case study research. Acad. Manag. Rev. 1989, 14, 532-550. [CrossRef]

62. Zimon, D.; Madzik, P.; Sroufe, R. Management systems and improving supply chain processes. Int. J. Retail. Distrib. Manag. 2019. [CrossRef]

63. Hsuan, J.; Skjoet-Larsen, T.; Kindra, A.; Kotzab, H. Managing the Global Supply Chain, 4th ed.; CBS Press: Frederiksberg, Denmark, 2015.

64. Schenkel, M.; Caniëls, M.C.J.; Krikke, H.; Van Der Laan, E. Understanding value creation in closed loop supply chains-Past findings and future directions. J. Manuf. Syst. 2015, 37, 729-745. [CrossRef]

65. Luzzini, D.; Brandon-Jones, E.; Brandon-Jones, A.; Spina, G. From sustainability commitment to performance: The role of intra- and inter-firm collaborative capabilities in the upstream supply chain. Int. J. Prod. Econ. 2015, 165, 51-63. [CrossRef]

66. Boström, M.; Jönsson, A.M.; Lockie, S.; Mol, A.P.J.; Oosterveer, P. Sustainable an responsible supply chain governance: Challenges and opportunities. J. Clean. Prod. 2015, 107, 1-7. [CrossRef]

67. Sroufe, R.; Gopalakrishna-Remani, V. Management, Social Sustainability, Reputation, and Financial Performance Relationships: An Empirical Examination of U.S. Firms. Organ. Environ. 2018, 32, 331-362. [CrossRef]

68. Zimon, D.; Tyan, J.; Sroufe, R. Implementing Sustainable Supply Chain Management: Reactive, Cooperative, and Dynamic Models. Sustainability 2019, 11, 7227. [CrossRef]

69. Testa, F.; Nucci, B.; Iraldo, F.; Appolloni, A.; Daddi, T. Removing obstacles to the implementation of LCA among SMEs: A collective strategy for exploiting recycled wool. J. Clean. Prod. 2017, 156, 923-931. [CrossRef]

70. Golini, R.; De Marchi, V.; Boffelli, A.; Kalchschmidt, M. Which governance structures drive economic, environmental, and social upgrading? A qualitative analysis in the assembly industries. Int. J. Prod. Econ. 2018, 203, 13-23. [CrossRef]

71. Cheng, W.; Appolloni, A.; Zhu, Q.; D'Amato, A. Green Public Procurement, missing concepts and future trends-A critical review. J. Clean. Prod. 2018, 176, 770-784. [CrossRef]

72. Bai, C.; Sarkis, J. Integrating sustainability into supplier selection with grey system and rough set methodologies. Int. J. Prod. Econ. 2010, 124, 252-264. [CrossRef]

73. Linton, T.; Vakil, B. Coronavirus Is Proving We Need More Resilient Supply Chains. Harvard Business Review, 5 March 2020. Available online: https://hbr.org/2020/03/coronavirus-is-proving-that-we-need-more-resilientsupply-chains (accessed on 6 April 2020). 